\title{
Fatty acid and Amino acid Profiles of Domestic and Wild Beluga (Huso huso) Roe and Impact on Fertilization Ratio
}

\author{
Mahmoudreza Ovissipour ${ }^{1}$ and Barbara Rasco ${ }^{2 *}$
}

${ }^{1}$ Department of Fisheries, Gorgan Agricultural Sciences and Natural Resources University, Gorgan, P.O. Box 49138, Iran

${ }^{2}$ School of Food Science, Washington State University, P.O. Box 646376, Pullman, Washington. USA 99164-6376

\begin{abstract}
A comparison of the fatty acid, amino acid and proximate composition between the roe of wild and cultivated beluga (Huso huso) sturgeon from Iran are presented here. The fatty acid profile varied between wild and cultivated sturgeons but there was no differences observed for proximate composition and amino acid profile. The wild sturgeon roe contained higher amounts of $n-3$ fatty acids particularly eicosapentaenoic acid (20:5n-3, EPA) (wild: $2.9 \%$, cultivated: $1.24 \%$ ) and docosahexaenoic acid (22:6n-3, DHA) (wild: $5.1 \%$, cultivated: $2.38 \%$ ). Linolenic and linoleic acids were the predominant fatty acids in roe from cultivated beluga, a reflection of diet and also a likely physiological adaptation to a higher temperature environment. Low levels of PUFA in cultivated sturgeon negatively affected fertilization and hatching ratios which were significantly lower than for the wild fish. Hence, in order to culture beluga, feed with higher fatty acid with more $n-3$ is necessary to reach high quality roe and fertilization and hatching ratio.
\end{abstract}

Keywords: Beluga; Roe; Fatty acids; Amino acids; Fertilization ratio

\section{Introduction}

Sturgeon populations worldwide are decreasing due to the overfishing, pollution and habitat destruction. Thus, in 1997 the Convention on International Trade in Endangered Species of Wild Fauna and Flora (CITES) limited caviar trade from Caspian Sea fishes by listing all sturgeon species on the Annex II of the convention [1]. This has promoted the development of sturgeon cultivation world wide to meet the demand for caviar, but unfortunately has not been all that effective in reducing poaching and sale of illicit product in the Commonwealth of Independent States (CIS) countries.

Demand for caviar on export markets is estimated at 500 tonnes annually [2,3] and is increasing as demand in Asia grows. Loss of wild harvest is reflected in capture figures from Iran, the country that has the most reliable harvest projections. The total sturgeon catches and caviar production in Iran in 1993 was 1710 and 106 t, while in 2009 it decreased to 178.41 and less than $10 \mathrm{t}$, respectively [4]. For beluga, total catch decreased from $116 \mathrm{t}$ in 1998 to $19.2 \mathrm{t}$ in 2009, and beluga caviar production has been decreased from $4.7 \mathrm{t}$ to $1.6 \mathrm{t}$ [4]. Consequently, the intensive culture of sturgeon developed over the past two decades has provided not only an alternative source for caviar and sturgeon meat for the world market, but remains critical for fisheries restoration efforts in the Caspian Sea and elsewhere, otherwise it is likely that a number of sturgeon populations would already have become extinct. Sturgeon culture has benefited much from the knowledge we have gained from salmonids and cyprinids culture both in terms of husbandry techniques and marketing and now provides a substantial source of sturgeon for the world market.

Sturgeon farming has been practised in Russia since 1875. However, until recently, such farming was exclusively used for fingerling production for restocking natural habitats to support declining wild sturgeon populations [5]. Over the past 20 years, commercial aquaculture of sturgeons has been developed for meat and caviar production, with these fishes being among the most promising temperate freshwater species for aquaculture in Western Europe [5] and Central Asia where most cultured sturgeons are produced for sale as whole fresh fish, and also in North America, South America, and China where the focus is on both meat production and caviar production.
Acipenser transmontanus, A. naccarii, A. baerii and A. gueldenstaedti are the most common sturgeon species reared commercially in Western Europe [5]. Iranian Fisheries Organization (IFO) produces up to 20 million sturgeon fingerlings annually for release into the Caspian Sea [4].

The beluga ( $H$. huso) is one of the most important sturgeons that are produced in Iran. The beluga sturgeon $(H$. huso) is an increasingly important aquaculture species in Russia, Eastern Europe, Turkey, Japan and Iran because of the dwindling natural sources for its caviar and meat. This fish is a commercially important and meat is sold both fresh and as frozen fillets. Therefore, the use of captive broodstock and production of sturgeon in culture should increase supply of caviar and reduce pressure on the wild stocks [6]. However, due to market pressure, at least in the former CIS countries, poaching has not decreased and pressure on the remaining wild stocks is excessive.

The important issue in sturgeon culture is that biochemical and gross composition of the fish and caviar, texture and taste of the product, should match that of wild sturgeon. In addition, nutritional factors associate with human health should be considered, although health factors would tend to influence the sales of sturgeon as a food fish less than lower priced fish such as catfish, canned tuna or Atlantic salmon. The importance of seafood in the diet is well-known particularly in its role in promoting cardiovascular health because of the high levels of polyunsaturated fatty acids [7]. These fatty acids also play an important role during sturgeon development [8].

Furthermore, fertilization and hatching are two important

*Corresponding author: Barbara Rasco, School of Food Science, Washington State University, P.O. Box 646376, Pullman, Washington, USA, 99164-6376. Tel: +1-509-335-1858, Fax: +1-509-335-4815; E-mail: rasco@wsu.edu

Received February 18, 2011; Accepted June 23, 2011; Published June 27, 2011

Citation: Ovissipour M, Rasco B (2011) Fatty acid and Amino acid Profiles of Domestic and Wild Beluga (Huso huso) Roe and Impact on Fertilization Ratio. Aquac Res Development 2:113. doi:10.4172/2155-9546.1000113

Copyright: (c) 2011 Ovissipour M, et al. This is an open-access article distributed under the terms of the Creative Commons Attribution License, which permits unrestricted use, distribution, and reproduction in any medium, provided the original author and source are credited. 
parameters, have been used to determine egg quality, which are also affected by a nutritional deficiency in broodstock diets. Indeed, one of the major nutritional factors that have been found to significantly affect reproductive performance in fish is the dietary essential fatty acid content [9]. Selective retention of DHA has also been found during embryogenesis and during starvation denoting the importance of this fatty acid for the developing embryo and larvae.

At present, studies available on lipid composition of cultured sturgeons are somewhat limited in the sense that they do not provide a comparison of cultured and wild beluga roe or meat [10-16]. Here, a comparison of the chemical composition (chemical, fatty acid and amino acid profiles) of the roe from farmed and wild caught beluga (H. huso) from the same watershed in the southern Caspian Sea is presented and how this may affect egg survival is presented.

\section{Materials and Methods}

\section{Egg collection}

Wild beluga ( $H$. huso) (Female: TL $=240 \pm 40 \mathrm{~cm}$, weight $=95 \pm 7$ $\mathrm{kg}$; Male: $\mathrm{TL}=180 \pm 20 \mathrm{~cm}$, weight $=82 \pm 5 \mathrm{~kg}$ ) were captured during their spawning season (February-March) on the south eastern coast of the Caspian Sea between Gorgan and Sari using gillnets fishing method and taken to the Marjani Hatchery Center (Gorgan, Iran). Eggs collected for the recruitment program were recovered from live fish that had been transferred to this hatchery. After $24 \mathrm{~h}$ adaptation, $50 \mathrm{~g}$ eggs from each five ovulating females were collected using surgically method, placed into separate $20 \mathrm{ml}$ plastic containers and immediately frozen in liquid nitrogen. Simultaneously, ovulated eggs from cultured beluga (Female: $\mathrm{TL}=190.6 \pm 12.5 \mathrm{~cm}$, weight $=94.6 \pm 9.3 \mathrm{~kg}$; Male: $160 \pm 10 \mathrm{~cm}$, weight: $73 \pm 6 \mathrm{~kg}$ ) were collected at the Rajaee Sturgeon Hatchery Center, in Sari, Iran in 2009, a culture facility about $120 \mathrm{~km}$ far from Marjani and eggs were recovered from three females as described above. These fish had been reared in fresh, warm $\left(19 \pm 2^{\circ} \mathrm{C}\right)$ artesial water for nine years from the larval stage at the Sari site. The fish were grown out in concrete tanks $\left(50 \mathrm{~m}^{3}\right)$. These fish were fed only minced Caracius auratus during the first year, and then a feed (Protein: 22.7\%, Fat: 5.6\% (from plant oils), Moisture: $49.46 \%$ ) which had been provided by the farm for the remaining 8 years. For further studies, 8 years fish were fed by new formulated feed (Protein: 44\%, Fat: 11\% (from plant oils and fish oil), Moisture: $35 \%$ ) for two years, and their hatching and fertilization ratio have been investigated. All roe samples were transferred to the lab in liquid nitrogen and kept at $-80^{\circ} \mathrm{C}$ until analyzed. Generally, sturgeon stocks in Caspian Sea have been decreased. Due to this, few number of beluga were available for current study.

\section{Chemical composition of sturgeon roe}

Roe were analyzed for moisture, protein, and ash using AOAC standard methods [17]. Briefly, protein by estimating the Kjeldahl nitrogen $(6.25 \times)$, moisture by heating at $105^{\circ} \mathrm{C}$ to constant weight, ash by incinerating in a crucible at $600^{\circ} \mathrm{C}$ for $18 \mathrm{~h}$ and lipid extraction has been performed according to Folch et al. [18].

\section{Fatty acid analysis}

Total lipids were extracted from the beluga eggs according to the Folch et al. [18] method and fatty acids methyl esters were prepared in n-hexane using $\mathrm{MgCl}_{2}$ as a catalyst. The gas chromatography analysis of the fatty acids methyl esters were performed on a Varian 3800 Gas Chromatograph (Palo Alto, CA, USA) equipped with a capillary column (SGE, BPX70, $120 \mathrm{~mm} \times 0.25 \mathrm{~mm} \mathrm{OD} \times 2 \mathrm{~mm}$ ID) and Flame Ionization Detector (FID). The carrier gas was helium at a pressure of $53.8 \mathrm{psi}$ and the flow rate of $1.5 \mathrm{ml} / \mathrm{min}$. The thermal gradient was $160^{\circ} \mathrm{C}$ for $10 \mathrm{~min}$, then increased by $2^{\circ} \mathrm{C} / \mathrm{min}$ to $180^{\circ} \mathrm{C}$ and held at $180^{\circ} \mathrm{C}$ for $85 \mathrm{~min}$.

\section{Amino acid analysis}

In order to eggs amino acid profile determination, eggs were first defatted $[19,20]$. Then, low fat residues were freeze dried at $-60^{\circ} \mathrm{C}$ (Operon, FDU-7012, Gyeonggi-do, South Korea). Sample preparation was conducted by hydrolysis with $6 \mathrm{M} \mathrm{HCl}$ at $110^{\circ} \mathrm{C}$ for 24 $\mathrm{h}$ and derivatisation using $o$-phthaldialdehyde (OPA) prior to HPLC analysis [20]. The total amino acids were analyzed by the Knauer (Berlin, Germany) HPLC unit using C18 column $(1.8 \mu \mathrm{m}, 2 \times 150 \mathrm{~mm})$

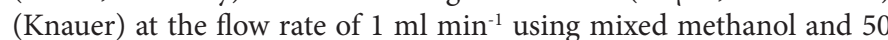
mM sodium acetate buffer ( $\mathrm{pH}$ 7) (Merck, Darmstadt, Germany) as the mobile phase with a fluorescence detector (RF-530, Knauer). Amino acid profiles were calculated using ChromGate ${ }^{\infty}$ software (Knauer) based on the amino acid standard peaks (Sigma Chemical Co.) as grams amino acid per 100 gram dry powder sample. Proline, hydroxyproline, cysteine and tryptophan were not recovered.

\section{Protein Efficiency Ratio}

One of the most important scores for evaluating the nutritional value of proteins is the protein efficiency ratio (PER) which measures protein quality by feeding a diet containing $10 \%$ of the test protein to rats and measuring their weight gain. This is an expensive and timeconsuming method. An alternative is to estimate protein quality using empirical models initially developed by Alsmeyer et al. [21] and Lee et al. [22] for predicting PER values. These equations were used in this study with the algorithm presented here:

$$
\begin{aligned}
& \text { PER }=-0.468+0.454[\mathrm{Leu}]-0.104[\mathrm{Tyr}] \\
& \text { PER }=-1.816+0.435[\mathrm{Met}]+0.780[\mathrm{Leu}]+0.211[\mathrm{His}]-0.944[\mathrm{Tyr}] \\
& \text { PER }=0.08084\left[\mathrm{X}_{7}\right]-0.1094 \\
& \text { PER }=0.06320\left[\mathrm{X}_{10}\right]-0.1539
\end{aligned}
$$

Where $\mathrm{X}_{7}=\mathrm{Thr}+\mathrm{Val}+\mathrm{Met}+\mathrm{Ile}+\mathrm{Leu}+\mathrm{Phe}+$ Lys and $\mathrm{X}_{10}=\mathrm{X}_{7}$ + His + Arg + Tyr

\section{Fertilization Ratio}

In order to fertilize eggs, fish were transferred to the propagation hall. Then, the fish were wiped with towels and eggs put into plastic bowels by applying a cut on the abdomen. The coelomic fluid was removed by pouring the eggs onto a screen suspended over a beaker and egg immediately used for propagation. In order to propagation, three wild male sperms have been used for wild beluga, and three cultured male sperms have been applied for cultured beluga. The eggs were then inseminated with milt and after eliminating adhesiveness [23], eggs were placed into Yoshchenko incubators (almost 28000 eggs per each incubator) in running freshwater system at $17-19^{\circ} \mathrm{C}$.

Fertilization rate was determined according to Dettlaff et al. [23]. For this purpose, 70-90 eggs were sampled randomly from each incubator in the time of second mitosis division which usually the second division occurs $3-4$ hour after fertilization in $17-18^{\circ} \mathrm{C}$ in sturgeons. Afterward, sample each egg batch were fixed in formalin solution $(5 \mathrm{~mL}$ formalin $(40 \%)+45 \mathrm{~mL}$ water) and then, eggs were investigated using a Stereomicroscope. The eggs with four blastomeres in animal pole were considered as fertilized eggs and others without cleavage, with more than four blastomeres and damaged eggs were considered as unfertilized eggs. After 6 days of incubation, larvae hatched. Hatching rate was determined by counting the number of free 
Citation: Ovissipour M, Rasco B (2011) Fatty acid and Amino acid Profiles of Domestic and Wild Beluga (Huso huso) Roe and Impact on Fertilization Ratio. J Aquac Res Development 2:113. doi:10.4172/2155-9546.1000113

Page 3 of 6

larvae and the number of eggs that did not hatch after 24 hours [24].

\section{Statistical analysis}

An unpaired $t$-test and one-way analysis of variance (Duncan's multiple test) using the Statistical Package for the Social Sciences (SPSS) software, release 16.0 (SPSS Inc., Chicago, IL, USA) at a probability level of $\mathrm{P}<0.05$ were used.

\section{Results and Discussion}

Fatty acid profile, chemical composition and fertilization ratio

The proximate composition of the beluga roe, both cultivated and wild, were within the range reported for sturgeon roe by other researchers (Table 1) $[25,26]$. However the fatty acid profile of the cultivated and wild sturgeon roes was different and it is likely that the reduced levels of polyunsaturated fatty acids negatively affected fertilization ratio in the cultivated beluga sturgeon. The results of fertilization and hatching ratio for 8 and 10 years old fish are presented in Figure 1. The fertilization rate was significantly lower in the cultivated beluga, $45 \%$ compared to $81 \%$ for the wild beluga in 8 years old fish. While in 10 years fish which had been fed by improved diet for two years, fertilization rate was significantly higher than 8 years old fish $(\mathrm{P}<0.05)$ with no significant difference compared to 8 years old wild beluga $(\mathrm{P}>0.05)$. It has been demonstrated that, sperm fatty acid composition depends upon the essential fatty acid content of broodstock diet. Both EPA (eicosapentaenoic acid) and AA (arachidonic acid) are involved in cell-mediated functions and are precursors of eicosanoids and they are known to be a precursor of prostaglandins (PG). Both of them modulate steroidogenesis in the fish testis. Thus, the timing of spermiation may be delayed and subsequently fertilization rates reduced by depressed steroidogenesis caused by a broodstock EFA deficiency or fatty acid imbalance. In current study, sperms which have been applied to fertilize the cultured beluga eggs, were provided from cultured male, which fed by same diet. Hence, because of the diet, it seems that fatty acid composition was not in well balance $[9,27]$.

In addition, in 8 years old beluga embryos from the cultivated fish underwent growth through the small yolk plug stage (stage 17) normally, but after reaching stages of 24 abnormities were observed in the majority of the cultivated embryos with only a small number of reaching the hatchling stage (stage 35). Even after this stage was reached, all of the embryos from all of the cultivated fish died off gradually. While, wild and 10 years domestic beluga embryos developed normally with 70 and $68 \%$ of hatching rate, respectively, with no significant differences $(\mathrm{P}>0.05)$. This difference in fertilization ratio and survival

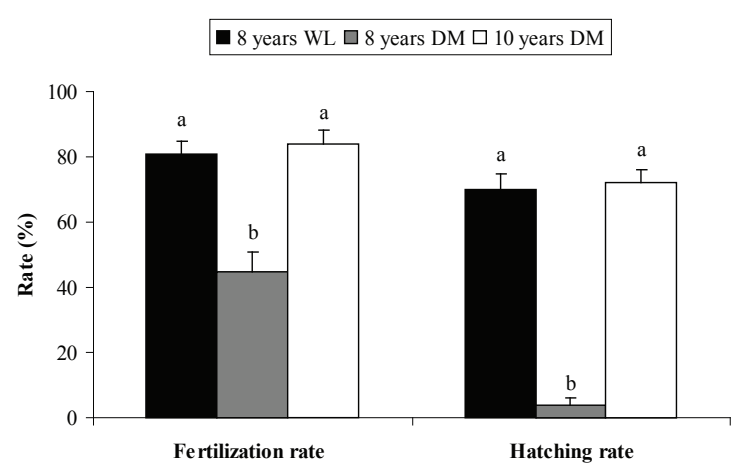

Figure 1: Fertilization and hatching rate in domestic (DM) and wild (WL) beluga at the age of 8 and 10 .

\begin{tabular}{|l|l|l|l|}
\hline Fatty acid $(\% w t)$ & $\begin{array}{l}\text { Cultivated beluga } \\
(n=3)\end{array}$ & Wild beluga $(n=5)$ & $P$-value \\
\hline $14: 00$ & $0.65 \pm 0.08$ & $1.5 \pm 0.28$ & 0.004 \\
\hline $14: 1 n 5$ & $0.44 \pm 0.04$ & $0.83 \pm 0.07$ & 0.000 \\
\hline $16: 00$ & $27.46 \pm 0.65$ & $29.88 \pm 1.24$ & 0.029 \\
\hline $16: 1 n 7$ & $3.48 \pm 0.26$ & $9.65 \pm 0.54$ & 0.000 \\
\hline $18: 00$ & $4.45 \pm 0.21$ & $2.32 \pm 0.18$ & 0.000 \\
\hline $18: 1 n 9$ & $33.72 \pm 1.25$ & $29.1 \pm 0.65$ & 0.001 \\
\hline $18: 1 n 7$ & $2.40 \pm 0.25$ & $2.94 \pm 0.2$ & 0.023 \\
\hline $18: 2 n 6$ & $11.42 \pm 0.26$ & $0.78 \pm 0.05$ & 0.000 \\
\hline $18: 3 n 3$ & $0.93 \pm 0.04$ & $0.3 \pm 0.02$ & 0.007 \\
\hline $20: 1 n 9$ & $0.62 \pm 0.03$ & $0.46 \pm 0.01$ & 0.000 \\
\hline $20: 2 n 6$ & $0.77 \pm 0.04$ & $0.38 \pm 0.03$ & 0.000 \\
\hline $20: 4 n 6$ AA & $2.69 \pm 0.09$ & $6.2 \pm 0.2$ & 0.000 \\
\hline $22: 1 n 9$ & $0.11 \pm 0.02$ & $0.17 \pm 0.01$ & 0.006 \\
\hline $20: 5 n 3$ EPA & $1.24 \pm 0.12$ & $2.9 \pm 0.13$ & 0.000 \\
\hline $22: 5 n 3$ DPA & $0.08 \pm 0.01$ & $0.53 \pm 0.31$ & 0.000 \\
\hline $22: 6 n 3$ DHA & $2.38 \pm 0.29$ & $5.1 \pm 0.34$ & 0.000 \\
\hline SAFA & 32.5 & 33.7 & 0.153 \\
\hline PUFA & 19.52 & 16.19 & 0.000 \\
\hline MUFA & 41.68 & 43.45 & 0.118 \\
\hline HUFA & 6.40 & 14.72 & 0.000 \\
\hline Total n-6 & 14.87 & 7.37 & 0.000 \\
\hline Total n-3 & 4.64 & 8.82 & 0.000 \\
\hline n-3/n-6 & 0.32 & 1.195 & 0.000 \\
\hline Chemical composition $(\%)$ & $15.11 \pm 0.97$ & 0.396 \\
\hline Protein & $14.56 \pm 0.2$ & $14.87 \pm 1$ & 0.659 \\
\hline Fat & $14.55 \pm 0.6$ & $64.1 \pm 2.1$ & 0.655 \\
\hline Moisture & $64.83 \pm 0.46$ & $4.2 \pm 0.65$ & 0.567 \\
\hline Ash & $4.51 \pm 0.91$ & & \\
\hline & & & \\
\hline & & & \\
\hline
\end{tabular}

avalues are the Mean \pm SD

Table 1: Fatty acid and chemical composition of roe from cultivated and wild beluga ${ }^{a}$

can be explained at least in part by differences in fatty acid composition between the roe from cultivated and wild fish (Table 1).

Several nutrients are essential for the normal development of the embryo, and their optimum level in broodstock diets improves egg morphology and hatching rates. It is well established that n-3 fatty acids play important roles in larvae growth and development [28]. These fatty acids are important as structural components of cell membranes as well as for physiological functions such as development of normal rod vision [28]. Fatty acids are also important for embryonic energy and developmental requirements [8], and perhaps in oocyte regulation $[8,9]$. The fatty acid composition of the female gonad is greatly affected by the dietary fatty acid content, which in turn significantly influences egg quality within a short period of time. A positive correlation has been observed between the levels of $n$ - 3 HUFA in the diet and the eggs with the EPA concentration being more readily affected by dietary $n-3$ HUFA than DHA (docosahexaenoic acid) [9].

Because egg quality is an important limiting factor in the mass production of fish larvae essential in aquaculture operations [27], attempts have been made to use lipid and fatty acid content as indicators of egg quality.

The results of fatty acid profiles in current study showed significant differences between wild and domestic beluga roes (Table 1) indicating that 16:0 was the prominent saturated fatty acid (SAFA) in both domestic and wild beluga roes. Relatively high amounts of palmitic acid (16:00) have been observed in cultured gulf sturgeon (Acipenser oxyrinchus desotoi) muscle [11] compared to the muscle of wild sturgeon. Mol and 
Turan [26] reported that palmitic acid was the most abundant SAFA in beluga caviar compare to other sturgeons caviar. While there is no available data comparing cultivated beluga and wild roe.

In addition, 18:1n-9 was the most abundant fatty acid in monounsaturated fatty acids (MUFA). Others have reported that 18:1n9 is the most common fatty acid in sturgeon and other fish eggs and tissues $[6,26,29-33]$. The results of this study show that MUFAs were higher in wild than in domestic beluga. The amount of linoleic acid $(18: 2 n-6)$ was much greater in the cultivated beluga eggs than in wild ones. The same tendency was also found in the lipid profile of ovulated eggs of wild and cultured turbot (Scophthalmus maximus) [30], striped bass (Morone saxatilis) [32] and white sturgeon [6] and is a reflection of dietary fat intake $[2,6,11,30]$. In addition, Hosseini et al. [33] compared the effect of three different diets including fish oil, soybean oil and canola oil on muscle fatty acids profiles in cultivated beluga ( $H$. huso). They have reported that diet contained fish oil resulted in higher MUFA in muscle than soybean oil.

Culturists have recognized that unsaturated fatty acids in earlier commercial diets are low and have reformulated diets so that the level of linoleic acid in the roe from the cultivated fish will be similar to that of wild fish [6]. The selection of dietary lipid sources is important, and using sunflower oil in diet can elevate linoleic acid in beluga muscle to levels that are higher than for a fish oil based diet [33].

The overall polyunsaturated fatty acids (PUFAs) content in wild fish roe was significantly lower than in cultivated fish in this study, however the proportion of the fatty acids were significantly different. Wild fish ova neutral lipids can have significantly lower proportions of total PUFAs compared to farmed fish (A. transmontanus, A. fulvescens) [6] and this is due to the higher quality of linolenic acid (18:3n-3) in diet of the farmed fish. Similar results have also been reported in cultured stellate sturgeon (A. stellatus) in Romania [2] and in other studies of cultivated beluga fatty acid composition of muscle tissue [33].

Home viscous adaptation in response to environmental temperature is a primary reason for the prominence of $n$-3 PUFAs in the tissues of

\begin{tabular}{|c|c|c|c|}
\hline Amino acid $^{b}$ & $\mathrm{DM}(n=3)$ & WD $(n=5)$ & $P$-value \\
\hline Histidine $^{a}$ & $3.5 \pm 0.3$ & $3.7 \pm 0.17$ & 0.340 \\
\hline Isoleucine $^{a}$ & $7.33 \pm 0.06$ & $7.34 \pm 0.07$ & 0.998 \\
\hline Lysine $^{a}$ & $9.05 \pm 0.1$ & $9.01 \pm 0.05$ & 0.142 \\
\hline Leucine $^{a}$ & $0.88 \pm 0.02$ & $0.89 \pm 0.04$ & 0.240 \\
\hline Methionine $^{a}$ & $2.46 \pm 0.28$ & $2.31 \pm 0.19$ & 0.446 \\
\hline Pheny lalanine ${ }^{a}$ & $3.05 \pm 0.01$ & $3.07 \pm 0.09$ & 0.767 \\
\hline Tyrosine & $0.27 \pm 0.07$ & $0.316 \pm 0.05$ & 0.549 \\
\hline Threonine $^{a}$ & $6.48 \pm 0.21$ & $6.56 \pm 0.20$ & 0.858 \\
\hline Tryptophan ${ }^{a}$ & - & - & - \\
\hline Arginine $^{a}$ & $9.03 \pm 0.22$ & $8.67 \pm 0.20$ & 0.920 \\
\hline Valine $^{a}$ & $8.66 \pm 0.09$ & $9.01 \pm 0.12$ & 0.267 \\
\hline Aspartic acid & $10.53 \pm 0.32$ & $10.33 \pm 0.19$ & 0.255 \\
\hline Glysine & $5.17 \pm 0.12$ & $5.38 \pm 0.13$ & 0.667 \\
\hline Alanine & $2.67 \pm 0.12$ & $2.7 \pm 0.11$ & 0.959 \\
\hline Serine & $12.47 \pm 0.38$ & $13.03 \pm 0.13$ & 0.115 \\
\hline Glutamic acid & $16.46 \pm 0.36$ & $15.34 \pm 0.13$ & 0.068 \\
\hline$\sum \mathrm{AA}$ & 98.03 & 97.88 & \\
\hline$\sum \mathrm{EAA}$ & 50.44 & 50.67 & \\
\hline$\sum$ NEAA & 47.58 & 47.11 & \\
\hline
\end{tabular}

aEssential amino acids, in terms of EAA

${ }^{b}$ Values are the Mean \pm SD

Table 2: Amino acid composition of cultivated (DM) $(n=3)$ and wild (WL) $(n=5)$ beluga roe. poikilotherms such as marine fish [34]. In current study, the cultivated beluga were cultured at $19^{\circ} \mathrm{C}$ in freshwater for nine years and fed a plant oil containing diet. Due to this, linolenic and linoleic acid levels were both higher in the roe of the cultivated sturgeons compared to the wild ones, but the levels of EPA and DHA were lower.

The lower levels of eicosapentaenoic acid (20:5n-3, EPA) $(1.24 \%)$ and docosahexaenoic acid (22:6n-3, DHA) (2.38\%) in lipids of eggs from the cultivated fish were observed in this study. Gessner et al. [2] found a similar trend for EPA and DHA in wild and cultured stellate (A. stellatus). It has been documented that $n-3$ fatty acids are more important for fish growth and reproduction than are $n-6$ fatty acids and that the $n-3 / n-6$ is important for overall fish health.

Our findings show that for the wild beluga roe, the total $n-3(8.82 \%)$ was two times higher than for the cultivated beluga (4.64\%). However, the $n-6$ levels were also higher in cultured beluga. Consequently, the $n-3 / n-6$ ratio was higher in wild beluga than this in cultured fish and this ratio has been shown to be important in reproductive potential and overall health of other cultured finfish. For example, the eggs of wild Chinook salmon (Oncorhynchus tshawytscha) contained a significantly greater proportion of $n-3$ fatty acids than cultured fish [29] and in stellate (A. stellatus) [2]. Under these conditions, the cultivated fish had lower energy reserves and were in a poorer overall health condition.

The fatty acid profile of beluga roes could be used as an index to determine fish origin and diet, and with further investigation, could be used as a prediction for roe fertilization success and larval survival. Because gametogenesis in Caspian sturgeons can be completed entirely in either a marine or freshwater environment, a bridge between the dietary pool and ovarian fatty acid composition reflects either "marine" or "freshwater" characteristics based upon dietary sources. Linoleic and linolenic acids in both fractions illustrated predominance of those fatty acids in freshwater food chains [35], whereas polyunsaturated levels also reflect the metabolic requirement for long chain $n$-3 PUFA [6].

The fatty acids composition of the diets currently fed to cultivated beluga may not be appropriate for successful egg embryo development, and should be adjusted so that the fatty acid profile of the roe from cultivated sturgeon more closely approximates that of the wild fish. But it will also be important with recruitment of these valuable fish for broodstock in Caspian Sea region to maintain the broodstock on a diet with the appropriate fatty acid ratio maintained in their roe to increase the $n-3 / n-6$ ratio in cultivated beluga and thereby improving the fertilization rate.

\section{Amino acid composition and PER}

The amino acid composition for roe from wild and cultivated beluga sturgeons is presented in Table 2. No significant differences were observed in essential or non-essential amino acids or in amino acids most closely associated with attractants or flavor. This indicates that the minimal protein requirement for the production of oocytes in both beluga groups is being met and the lower percentage of fertilized eggs obtained from the domestic females was not likely related to the amount or ratio of amino acids present in the spawned eggs. Tamura et al. [36] reported that the feed protein source can result in alteration of the amino acid profile in stripped mullet (Mugil cephalus) roe. In current study, the cultivated belugas were fed on a diet containing minced Caracius auratus and kilka (Clupenollea sp.) meal to mimic the food source that these animals consume in the wild. Wild beluga in the Caspian Sea commonly feed on kilka and Cyprinidae such as Cyprinus carpio, or Rutilus rutilus and gobiids. 
Citation: Ovissipour M, Rasco B (2011) Fatty acid and Amino acid Profiles of Domestic and Wild Beluga (Huso huso) Roe and Impact on Fertilization Ratio. J Aquac Res Development 2:113. doi:10.4172/2155-9546.1000113

\begin{tabular}{|l|l|l|}
\hline PER Equations & \\
\hline$-0.468+0.454[\mathrm{Leu}]-0.104[\mathrm{Tyr}]$ & Cultivated Beluga & Wild Beluga \\
\hline $\begin{array}{l}-1.816+0.435[\mathrm{Met}]+0.780[\mathrm{Leu}]+0.211 \\
{[\mathrm{His}]-0.944[\mathrm{Tyr}]}\end{array}$ & 3.61344 & 3.634168 \\
\hline $0.08084\left[\mathrm{X}_{7}\right]-0.1094$ & 6.78885 & 6.77633 \\
\hline $0.06320\left[\mathrm{X}_{10}\right]-0.1539$ & 2.95767 & 2.98661 \\
\hline
\end{tabular}

${ }^{a} X_{7}=T h r+\mathrm{Val}+$ Met + lle + Leu + Phe + Lys

$\mathrm{X}_{10}=\mathrm{X}_{7}+\mathrm{His}+\mathrm{Arg}+\mathrm{Tyr}$

Table 3: Prediction equation for PER.

Glutamic acid and aspartic acid were the amino acids in highest concentration in beluga roes (Table 2). Glutamic acid and aspartic acid have been reported as the major components in fish roes by other researchers $[3,26,37,38]$. Beluga roes contain considerable serine as do other sturgeon roes [26,39].

Valine and lysine are the other two important amino acids in fish roes. Lysine is one of the major amino acids, and its content has been the highest for salmon roes [37]. Souci et al. [39] reports the lysine content of black caviar to be $2070 \mathrm{mg} / 100 \mathrm{~g}$ roe, and it has been estimated as $4029 \mathrm{mg} / 100 \mathrm{~g}$ roe, $2647 \mathrm{mg} / 100 \mathrm{~g}$ roe, and $5595 \mathrm{mg} / 100 \mathrm{~g}$ roe $(\mathrm{p}<$ 0.05 ) for Beluga, Imperial, and Osetra-type caviars, respectively, by Mol and Turan [26].

Calculated PER for cultivated and wild beluga roe are presented in Table 3 and no significant differences in these two values were observed, supporting the conclusion that the amino acid balance is not a likely factor in the low fertilization rate or embryo survival observed in this study.

In conclusion, the results of this study showed that the feed quality affects both fertilization and hatching ratio. In addition, lack of $n-3$ in broodstock diet has influence on egg fatty acid composition which is important both for consumption health and artificial propagation. By improving high quality diet, it could be possible to increase eggs quality and hatching rate.

\section{Acknowledgment}

We would like to express our thanks to Dr. Rajabmohammad Nazari and Dr. Abbas Esmaeili-Molla (Rajaee Sturgeon Hatchery Center, Sari, Iran), Mr. Nour Mohammad Makhdomi (Marjani Sturgeon Hatchery Center, Gorgan, Iran) and Dr. Aria Babakhani (Guilan University, Rasht, Iran), for their technical support.

\section{References}

1. Raymakers C (2002) International trade in sturgeon and paddlefish speciesThe effect of CITES listing. Int Rev Hydrobiol 87: 525-537.

2. Gessner J, Wirth M, Kirschbaum F, Kruger A, Patriche N (2002) Caviar composition in wild and cultured sturgeons-impact of food sources on fatty acid composition and contaminant load. J Appl Ichthyol 18: 665-672.

3. Bledsoe GE, Bledsoe CD. Rasco AB (2003) Caviar and fish roe products. Crit Rev Food Sci Nutr 43: 317-356.

4. IFO (2009) Production reports of Iran fisheries organization. Iran Fisheries Organization Tehran Iran.

5. Williot P, Sabeau L, Gessner J, Arlati G, Bronzi P, et al. (2001) Sturgeon farming in Western Europe: recent developments and perspectives. Aquat Liv Res 14: 367-374

6. Czesny S, Dabrowski K, Christensen JE, VanEenennaam JP, Doroshov S (2000) Discrimination of wild and domestic origin of sturgeon ova based on lipids and fatty acid analysis. Aquaculture 189: 145-153.

7. Vaccaro AM, Buffa G, Messina M, Santulli A, Mazzola A (2005) Fatty acid composition of a cultured sturgeon hybrid (Acipenser naccarii $\times$ A. baerii). Food Chem 93: 627-631.

8. Tocher DR, Fraser AJ, Sargent JR, Gamble JC (1985) Fatty acid composition of phospholipids and neutral lipids during embryonic and early larval development in Atlantic herring, Clupeu harengus. Lipids 20: 69-74.

9. Izquierdo MS, Fernández-Palacios H, Tacon AGJ (2005) Effect of broodstock nutrition on reproductive performance of fish. Aquaculture 197: 25-42.

10. Badiani A, Anfossi P, Fiorentini L, Gatta PP, Manfredini M, et al. (1996) Nutritional composition of cultured sturgeon (Acipenser spp). J Food Comp Analys 9: 171-190.

11. Chen IC, Chapman FA, Wei Cl, Portier KM, O'Keefe SF (1995) Differentiation of cultured and wild sturgeon (Acipenser oxyrinchus desotoi) based on fatty acid composition. J Food Sci 60: 631-635.

12. Garcia-Gallego M, Sanz A, Domezain A, De la Higuera, M (1999) Agesize influence on tissue-lipid quality of the sturgeon Acipenser naccari from intensive culture. J Appl Ichthyol 15: 261-264.

13. McKenzie DJ, Piraccini G, Papini N, Galli C, Bronzi P, et al. (1997) Oxygen consumption and ventilatory reflex responses are influenced by dietary lipids in sturgeon. Fish Physiol Biochem 16: 365-379.

14. Naruse U, Oyaizu M, Hirota S (1989) Study on fatty acid composition and cholesterol content of cultured sturgeon (Bester $s p$ ). The Japanese Journal of Nutrition and Dietetics 47: 293-297.

15. Shimma Y, Shimma H (1968) Fatty acid composition of Acipenser baeri cultivated in Tokyo. Bull Freshwater Fish Res Lab (Tokyo) 18: 179-184.

16. Xu R, Hung SSO (1996) Effects of dietary lipids on the fatty acids composition of triglycerides and phospholipids in tissue of white sturgeon. Aquac Nutr 2 101-109.

17. AOAC (2000) In: Hortwitz, W. (ed.) Official Methods of Analysis of AOAC International. 17th edn AOAC International Gaithersburg MD USA.

18. Folch J, Lees M, Stanley GHS (1957) A simple method for the isolation and purification of total lipids from animal tissues. J Biol Chem 226: 497-509.

19. Ng WK, Hung SSO (1994) Amino acid composition of whole body, egg and selected tissues of white sturgeon Acipenser transmontanus. Aquaculture 126 329-339.

20. Antoine FR, Wei Cl, Littell RC, Marshall MR (1999) HPLC method for analysis of free amino acids in fish using o-Phthaldialdehyde precolumn derivatization. $J$ Agri Food Chem 47: 5100-5107.

21. Alsmeyer RH, Cunningham AE, Happich ML (1974) Equations predicting PER from amino acid analysis. Food Technol 28: 34-40.

22. Lee YB, Elliot JG, Rickansrud DA, Mugberg EC (1978) Predicting protein efficiency ratio by the chemical determinations of connective tissue content in meat. J Food Sci 43: 1359-1362.

23. Dettlaff TA, Ginsburg AS, Schmalhausen OI (1993) Sturgeon fishes, developmental biology and aquaculture. Verlag Berlin Heidelberg printed in Germany: Springer.

24. Gisbert E, Williot $P$ (2002) Influence of storage duration of ovulated eggs prio to fertilization on the early ontogenesis of Sterlet (Acipenser ruthenus) and Siberian sturgeon (Acipenser baeri). Intel Rev Hydrobiol 87: 605-612.

25. Caprino F, Moretti VM, Bellagamba F, Turchini GM, Busetto ML, et al. (2008) Fatty acid composition and volatile compounds of caviar from farmed white sturgeon (Acipenser transmontanus). Analytica Chimica Acta 617: 139-147.

26. Mol S, Turan S (2008) Comparison of proximate, fatty acid and amino acid compositions of various types of fish roes. Intel J Food Propert 11: 669-677.

27. Watanabe T (1985) Importance of the study of brood stock nutrition for further development of aquaculture. In Nutrition and Feeding in Fish (Cowey, C. B. Mackie, A. M. \& Bell, J. G., ed.). New York: Academic Press.

28. Bell MV, Sargent JR (1996) Lipid nutrition and fish recruitment. Mar Ecolo Progr Seri 134: 315-316.

29. Ashton HJ, Farkvan DO, March BE (1993) Fatty acid composition of lipids in the eggs and alevins from wild and cultured chinook salmon (Oncorhynchus tshawytscha). Can J Fish Aquat Sci 50: 648-655

30. Silversand C, Norberg B, Haux C (1996) Fatty-acid composition of ovulated eggs from wild and cultured turbot (Scophthalmus maximus) in relation to yolk and oil globule lipids. Mar Biol 125: 269-278.

31. Czesny S, Dabrowski K (1998) The effect of egg fatty acid concentrations on embryo viability in wild and domesticated walleye (Stizostedion vitreum). Aqua Liv Res 11: 371-378. 
Citation: Ovissipour M, Rasco B (2011) Fatty acid and Amino acid Profiles of Domestic and Wild Beluga (Huso huso) Roe and Impact on Fertilization Ratio. J Aquac Res Development 2:113. doi:10.4172/2155-9546.1000113

32. Gallagher ML, Paramore L, Alves D, Rulifson RA (1998) Comparison of phospholipid and fatty acid composition of wild and cultured striped bass eggs. J Fish Biol 52: 1218-1228.

33. Hosseini SV, Abedian-Kenari AM, Regenstein JM, Rezaei M, Nazari RM, et al (2010) Effects of alternative dietary lipid sources on growth performance and fatty acid composition of beluga sturgeon, Huso huso, Juveniles. J World Aquac Soci 41: 471-489.

34. Dey L, Buda C, Wilk T, Halver JE, Farkas T (1993) Molecular and structural composition of phospholipid membranes in livers of marine and freshwater fish in relation to temperature. Proc Natl Acad Sci USA 90: 7498-7502.

35. JJ, Tocher DR (1987). The lipid composition and biochemistry of freshwater fish. Prog Lipid Res 26: 281-347.

36. Tamura CS, Ako H, Lee CS (1992) Fatty acid and amino acid profiles of spawned eggs of stripped mullet, Mugil cephalus L. Aquaculture 105: 83-94.

37. Iwasaki M, Harada R (1985) Proximate and amino acid composition of the roe and muscle of selected marine species. J Food Sci 50:1585-1587.

38. Bekhit AED, Morton JD, Dawson CO, Zhao JH, Lee HYY (2009) Impact of maturity on the physicochemical and biochemical properties of Chinook salmon roe. Food Chem 117: 318-325.

39. Souci SW, Fachmann W, Kraut H (2000) Food Composition and Nutrition Tables; Medphorm Scientific Publishers: Stuttgart and CRC Press: Boca Raton. 